\title{
Sulfitobacter marinus sp. nov., isolated from seawater of the East Sea in Korea
}

Correspondence

Jung-Hoon Yoon

jhyoon@kribb.re.kr

\author{
Jung-Hoon Yoon, So-Jung Kang and Tae-Kwang Oh \\ Korea Research Institute of Bioscience and Biotechnology (KRIBB), PO Box 115, Yusong, \\ Taejon, Korea
}

\begin{abstract}
A Gram-negative, non-motile, rod- or oval-shaped Sulfitobacter-like bacterial strain, SW-265 ${ }^{\top}$, was isolated from seawater at Hwajinpo, Korea, and was subjected to a polyphasic taxonomic study. Strain SW-265 ${ }^{\top}$ grew optimally at $\mathrm{pH} 7.0-8.0$ and $30^{\circ} \mathrm{C}$ in the presence of $2 \%(\mathrm{w} / \mathrm{v}) \mathrm{NaCl}$. It contained $\mathrm{Q}-10$ as the predominant ubiquinone and $\mathrm{C}_{18: 1} \omega 7 \mathrm{c}$ as the major fatty acid. The DNA $\mathrm{G}+\mathrm{C}$ content was $57.8 \mathrm{~mol} \%$. A phylogenetic analysis based on 16S rRNA gene sequences showed that strain SW-265 ${ }^{\top}$ fell within the cluster comprising Sulfitobacter species. The levels of 16S rRNA gene sequence similarity between strain SW $-265^{\top}$ and the type strains of Sulfitobacter species ranged from 97.1 to $98.7 \%$. DNA-DNA relatedness data and differential phenotypic properties, together with the phylogenetic distinctiveness, demonstrated that strain $S W-265^{\top}$ differs from recognized Sulfitobacter species. On the basis of the phenotypic, phylogenetic and genetic data, strain SW-265 ${ }^{\top}$ represents a novel species of the genus Sulfitobacter, for which the name Sulfitobacter marinus sp. nov. is proposed. The type strain is SW- $265^{\top}(=\mathrm{KCTC}$ $12738^{\top}=$ JCM $13602^{\top}$ ).
\end{abstract}

The genus Sulfitobacter was first described by Sorokin (1995), and, at the time of writing, consists of five species with validly published names: Sulfitobacter pontiacus (Sorokin, 1995), Sulfitobacter mediterraneus (Pukall et al., 1999), Sulfitobacter brevis (Labrenz et al., 2000) and Sulfitobacter delicatus and Sulfitobacter dubius (Ivanova et al., 2004). In this study, we report on the taxonomic characterization of a Sulfitobacter-like bacterial strain, SW$265^{\mathrm{T}}$, which was isolated from seawater from the East Sea, Korea.

Strain SW-265 ${ }^{\mathrm{T}}$ was isolated, using the standard dilution plating technique, on marine agar 2216 (MA; Difco) at $25^{\circ} \mathrm{C}$. The following strains were used as reference strains: Sulfitobacter pontiacus DSM $10014^{\mathrm{T}}$, Sulfitobacter mediterraneus DSM $12244^{\mathrm{T}}$ and Sulfitobacter brevis DSM $11443^{\mathrm{T}}$, obtained from the Deutsche Sammlung von Mikroorganismen und Zellkulturen (Braunschweig, Germany), and Sulfitobacter delicatus KCTC $12547^{\mathrm{T}}$ and Sulfitobacter dubius KCTC $12546^{\mathrm{T}}$, obtained from the Korean Collection for Type Cultures (Taejon, Korea). The morphological, physiological and biochemical characteristics of strain SW-265 ${ }^{\mathrm{T}}$ were investigated using routine cultivation on MA at $30{ }^{\circ} \mathrm{C}$. Cell morphology was examined by light microscopy (E600; Nikon) and transmission

The GenBank/EMBL/DDBJ accession number for the $16 \mathrm{~S}$ rRNA gene sequence of strain $\mathrm{SW}-265^{\top}$ is DQ683726.

Biolog assimilation data for strain $\mathrm{SW}-265^{\top}$ are available in a supplementary table in IJSEM Online. electron microscopy. The presence of flagella was determined using transmission electron microscopy with cells from exponentially growing cultures. For transmission electron microscopic observation, cells were negatively stained with $1 \%(\mathrm{w} / \mathrm{v})$ phosphotungstic acid and the grids were examined after air-drying with a Philips CM-20 transmission electron microscope. Growth under anaerobic conditions was determined after incubation in a Forma anaerobic chamber on MA and MA supplemented with nitrate, both of which had been prepared anaerobically using nitrogen. Growth in the absence of $\mathrm{NaCl}$ was investigated using trypticase soy broth prepared according to the formula for the Difco medium, except that no $\mathrm{NaCl}$ was used. Growth at various $\mathrm{NaCl}$ concentrations was investigated in marine broth 2216 (Difco) or trypticase soy broth (Difco). Growth at various temperatures $\left(4-40{ }^{\circ} \mathrm{C}\right)$ was measured on MA. Catalase and oxidase activities and the hydrolysis of casein, starch and Tweens 20, 40, 60 and 80 were determined as described by Cowan \& Steel (1965). The hydrolysis of hypoxanthine, tyrosine and xanthine was tested on MA, using the substrate concentrations described by Cowan \& Steel (1965). The hydrolysis of aesculin, gelatin and urea and the reduction of nitrate were investigated as described previously (Lanyi, 1987), with the modification that artificial seawater was used in the preparation of the media. The artificial seawater contained $\left(1^{-1}\right.$ distilled water) $23.6 \mathrm{~g} \mathrm{NaCl}, 0.64 \mathrm{~g} \mathrm{KCl}, 4.53 \mathrm{~g} \mathrm{MgCl}_{2} \cdot 6 \mathrm{H}_{2} \mathrm{O}, 5.94 \mathrm{~g}$ $\mathrm{MgSO}_{4} .7 \mathrm{H}_{2} \mathrm{O}$ and $1.3 \mathrm{~g} \mathrm{CaCl}_{2} \cdot 2 \mathrm{H}_{2} \mathrm{O}$ (Bruns et al., 2001). $\mathrm{H}_{2} \mathrm{~S}$ production was tested as described previously (Bruns et al., 2001). Susceptibility to antibiotics was detected on 
Table 1. Differential phenotypic characteristics of strain $S W-265^{\top}$, Sulfitobacter species, Staleya guttiformis and O. indolifex

Taxa: 1, strain SW-265 ${ }^{\mathrm{T}}$; 2, Sulfitobacter pontiacus (data from Sorokin, 1995; Ivanova et al., 2004); 3, Sulfitobacter mediterraneus (Pukall et al., 1999; Ivanova et al., 2004); 4, Sulfitobacter brevis (Labrenz et al., 2000; Ivanova et al., 2004); 5, Sulfitobacter delicatus (Ivanova et al., 2004); 6, Sulfitobacter dubius (Ivanova et al., 2004); 7, Staleya guttiformis (Labrenz et al., 2000); 8, O. indolifex (Wagner-Döbler et al., 2004). Data shown in parentheses are for the type strains. All of the taxa shown are positive for catalase and oxidase. All are susceptible to ampicillin, carbenicillin, gentamicin, kanamycin, neomycin and oleandomycin (data for Sulfitobacter pontiacus, Sulfitobacter mediterraneus and Sulfitobacter brevis are from this study; not reported for Staleya guttiformis or O. indolifex). All of the taxa shown are negative for the Gram stain and for casein hydrolysis (not reported for Staleya guttiformis or O. indolifex). Symbols: +, positive; -, negative; ND, not determined or not described; w, weak.

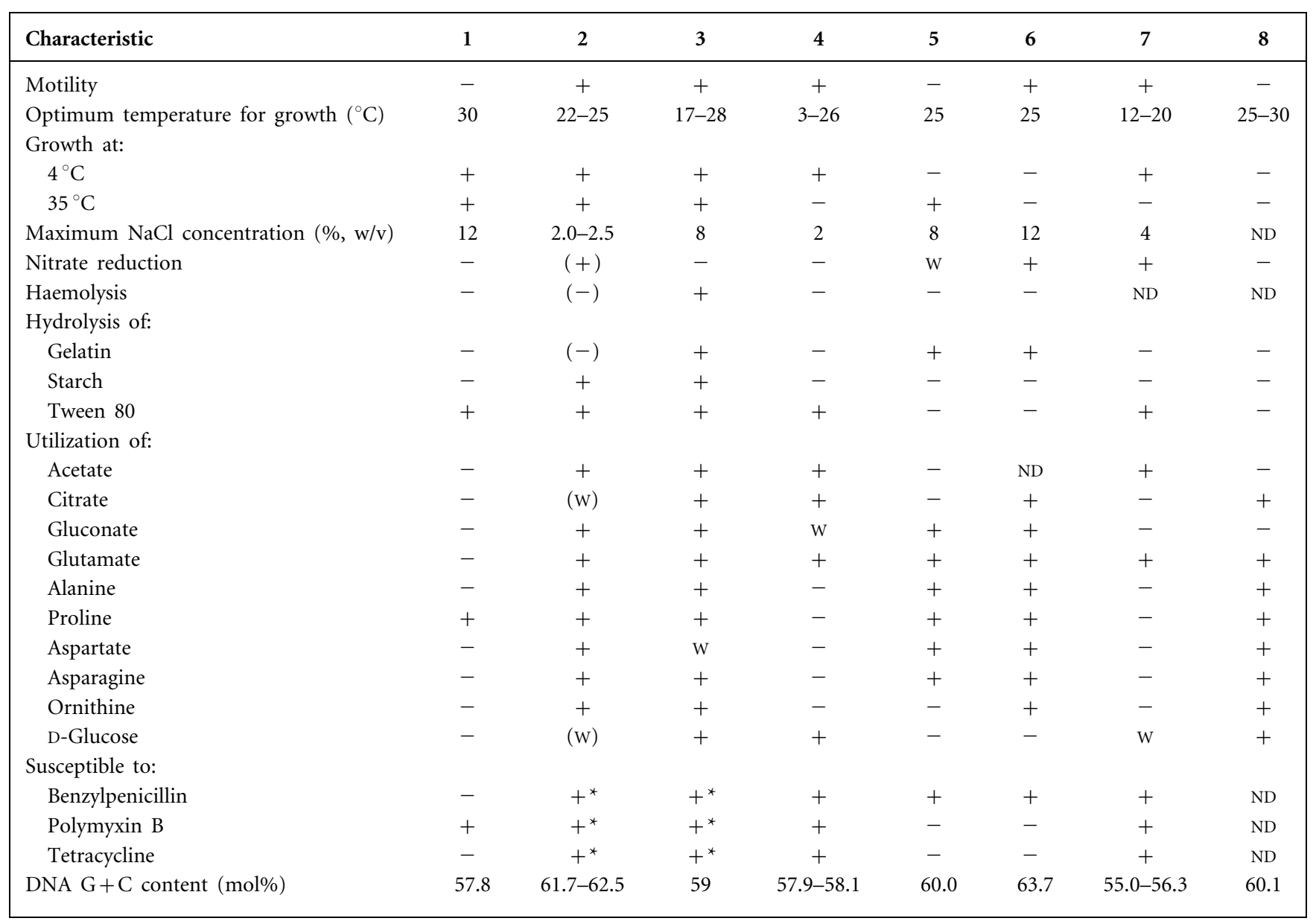

${ }^{*}$ Data from this study for the type strain.

MA plates by using filter-paper discs containing the following amounts of antibiotic: polymyxin B (100 U), streptomycin $(50 \mu \mathrm{g})$, penicillin $\mathrm{G}(20 \mathrm{U})$, chloramphenicol $(100 \mu \mathrm{g})$, ampicillin $(10 \mu \mathrm{g})$, cephalothin $(30 \mu \mathrm{g})$, gentamicin $(30 \mu \mathrm{g})$, novobiocin $(5 \mu \mathrm{g})$ and tetracycline $(30 \mu \mathrm{g})$. Haemolytic activity was recorded on MA with $5 \%$ defibrinated sheep blood. Acid production from carbohydrates was determined as described by Leifson (1963). The oxidation of various substrates was determined by using the Biolog GN2 MicroPlate assay as recommended by the manufacturer. Other physiological and biochemical tests were performed with the API 20E and API ZYM systems (bioMérieux).
Cell biomass for respiratory lipoquinone analysis and for DNA extraction was obtained from cultivation in marine broth at $30^{\circ} \mathrm{C}$. Chromosomal DNA was isolated and purified according to the method described by Yoon et al. (1996), with the exception that RNase T1 was used in combination with RNase A to minimize contamination with RNA. The $16 \mathrm{~S}$ rRNA gene was amplified by a PCR with two universal primers, as described previously (Yoon et al., 1998). Sequencing of the amplified 16S rRNA gene and phylogenetic analysis were performed as described by Yoon et al. (2003). Respiratory lipoquinones were analysed as described by Komagata \& Suzuki (1987), using reversedphase HPLC. For cellular fatty acid analysis, cell mass of 
strain SW $-265^{\mathrm{T}}$ was harvested from agar plates after cultivation for 3 days at $30^{\circ} \mathrm{C}$ on MA. Fatty acids were extracted and fatty acid methyl esters were prepared according to the standard protocol of the MIDI/Hewlett Packard Microbial Identification System (Sasser, 1990). The DNA $G+C$ content was determined by the method of Tamaoka \& Komagata (1984), with the modification that the DNA was hydrolysed using nuclease P1 (Boehringer Mannheim); the resultant nucleotides were analysed by reversed-phase HPLC. DNA-DNA hybridization was performed fluorometrically by the method of Ezaki et al. (1989), using photobiotin-labelled DNA probes and microdilution wells. Hybridization was performed with five replications for each sample. The highest and lowest values obtained in each sample were excluded, and the means of the remaining three values were quoted as the DNA-DNA relatedness values.

The morphological, cultural, physiological and biochemical characteristics of strain $\mathrm{SW}-265^{\mathrm{T}}$ are given in the species description (see below) or are shown in Table 1 and Supplementary Table S1 (available in IJSEM Online). The almost-complete 16S rRNA gene sequence of strain SW$265^{\mathrm{T}}$ determined in this study comprised $1420 \mathrm{nt}$, representing approximately $96 \%$ of the Escherichia coli $16 \mathrm{~S}$ rRNA gene sequence. In the phylogenetic tree based on the neighbour-joining algorithm, strain $\mathrm{SW}-265^{\mathrm{T}}$ fell within the clade comprising Sulfitobacter species (Fig. 1). Strain SW$265^{\mathrm{T}}$ exhibited $16 \mathrm{~S}$ rRNA gene sequence similarity values of 97.1-98.7\% with respect to the type strains of Sulfitobacter species and showed values of $97.0-97.1 \%$ with respect to Staleya guttiformis EL-38 ${ }^{\mathrm{T}}$ and Oceanibulbus indolifex HEL $45^{\mathrm{T}}$. Sequence similarities with respect to all other species included in the phylogenetic analysis were below $96.6 \%$. The fatty acid profile of strain $\mathrm{SW}-265^{\mathrm{T}}$ was composed of the following (each constituting $>0.5 \%$ of total fatty acids): unsaturated fatty acids $\mathrm{C}_{18: 1} \omega 7 c(77.1 \%)$ and $\mathrm{C}_{17: 1} \omega 8 c(0.5 \%)$; straight-chain fatty acids $\mathrm{C}_{16: 0}$ $(8.3 \%), \mathrm{C}_{17: 0}(0.7 \%), \mathrm{C}_{18: 0}(0.6 \%)$ and $\mathrm{C}_{15: 0}(0.6 \%)$; 11-methyl $\mathrm{C}_{18: 1} \omega 7 c(6.9 \%)$; hydroxy fatty acid $\mathrm{C}_{10: 0} 3-\mathrm{OH}$ $(3.6 \%)$; and summed feature $3\left(\mathrm{C}_{16: 1} \omega 7 \mathrm{c}\right.$ and/or iso- $\mathrm{C}_{15: 0}$ $2-\mathrm{OH} ; 1.0 \%)$. This fatty acid profile was similar to that of Sulfitobacter species (Pukall et al., 1999; Labrenz et al., 2000; Ivanova et al., 2004). The predominant respiratory lipoquinone detected in strain $\mathrm{SW}-265^{\mathrm{T}}$ was $\mathrm{Q}-10$, at a peak area ratio of approximately $89 \%$. The DNA G+C content of strain $\mathrm{SW}-265^{\mathrm{T}}$ was $57.8 \mathrm{~mol} \%$. The mean levels of DNA-DNA relatedness between strain SW $-265^{\mathrm{T}}$ and the type strains of five Sulfitobacter species were in the range 9-21\%, indicating that the novel strain represents a genomic species that is distinct from the five Sulfitobacter species (Wayne et al., 1987). The differential phenotypic properties, together with the phylogenetic distinctiveness and the DNA-DNA relatedness data, were sufficient to categorize strain $\mathrm{SW}-265^{\mathrm{T}}$ as a member of a species that is distinct from the recognized Sulfitobacter species (Table 1) (Stackebrandt \& Goebel, 1994). Therefore, on the basis of the data presented, strain $\mathrm{SW}-265^{\mathrm{T}}$ represents a novel species of the genus Sulfitobacter, for which the name Sulfitobacter marinus sp. nov. is proposed.

\section{Description of Sulfitobacter marinus sp. nov.}

Sulfitobacter marinus (ma'ri.nus. L. masc. adj. marinus pertaining to the sea).

Cells are Gram-negative and rod- or oval-shaped $(0.2-0.5 \times 0.6-1.5 \mu \mathrm{m})$. After 3 days incubation at $30^{\circ} \mathrm{C}$ on MA, colonies are circular, slightly convex, smooth, glistening, cream-coloured and $0.5-1.0 \mathrm{~mm}$ in diameter. Growth occurs at 4 and $35^{\circ} \mathrm{C}$, but not at $36^{\circ} \mathrm{C}$. The optimal $\mathrm{pH}$ for growth is between 7.0 and 8.0; growth occurs at $\mathrm{pH} 5.0$, but not at $\mathrm{pH}$ 4.5. Growth occurs in the presence of $12 \%(\mathrm{w} / \mathrm{v}) \mathrm{NaCl}$, but not in the absence of $\mathrm{NaCl}$ or in the presence of more than $13 \%(\mathrm{w} / \mathrm{v}) \mathrm{NaCl}$. Anaerobic growth does not occur on MA or on MA supplemented with nitrate. Urease-negative. Hypoxanthine, L-tyrosine and Tweens 20, 40 and 60 are hydrolysed, but aesculin and xanthine are not. $\mathrm{H}_{2} \mathrm{~S}$ and indole are not produced. Arginine dihydrolase, lysine decarboxylase, ornithine decarboxylase and tryptophan deaminase are absent. In assays with the API ZYM system, alkaline phosphatase, esterase (C4), esterase lipase (C8) and leucine arylamidase are present, but lipase (C14), valine arylamidase, cystine arylamidase, trypsin, $\alpha$-chymotrypsin, acid phosphatase, naphthol-AS-BI-phosphohydrolase, $\alpha$-galactosidase, $\beta$-galactosidase, $\beta$-glucuronidase, $\alpha$-glucosidase, $\beta$-glucosidase, $N$-acetyl- $\beta$-glucosaminidase, $\alpha$-mannosidase and $\alpha$-fucosidase are absent. Acid is produced from D-mannitol and D-sorbitol, but not from L-arabinose, D-cellobiose, D-fructose, D-galactose, D-glucose, lactose, maltose, D-mannose, D-melezitose, melibiose, D-raffinose, L-rhamnose, D-ribose, sucrose, D-trehalose, Dxylose or myo-inositol. Susceptible to chloramphenicol, cephalothin, novobiocin and streptomycin, but not to

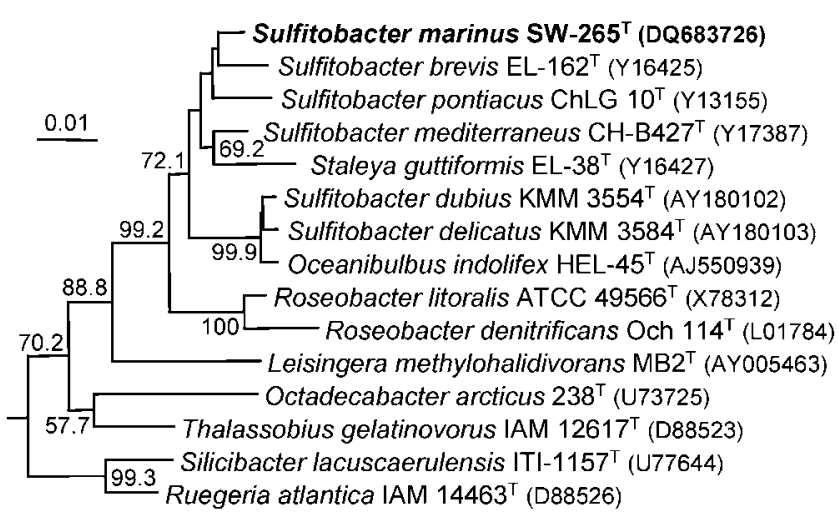

Fig. 1. Neighbour-joining phylogenetic tree, based on $16 \mathrm{~S}$ rRNA gene sequences, showing the positions of strain SW$265^{\top}$, Sulfitobacter species and some other related taxa. Bootstrap percentages (from 1000 replications) greater than $50 \%$ are shown at branch points. Agrobacterium aggregata IAM $12614^{\top}$ was used as an outgroup (not shown). Bar, 0.01 substitutions per nucleotide position. 
lincomycin. The predominant ubiquinone is Q-10. The major fatty acid (constituting $>10 \%$ of total fatty acids) is $\mathrm{C}_{18: 1} \omega 7 c(77.1 \%)$. The DNA G $+\mathrm{C}$ content is $57.8 \mathrm{~mol} \%$ (determined by HPLC). Other phenotypic characteristics are given in Table 1 and in Supplementary Table S1 (available in IJSEM Online).

The type strain, SW $-265^{\mathrm{T}}\left(=\mathrm{KCTC} 12738^{\mathrm{T}}=\mathrm{JCM} 13602^{\mathrm{T}}\right)$, was isolated from seawater at Hwajinpo (East Sea, Korea).

\section{Acknowledgements}

This work was supported by the 21C Frontier Program of Microbial Genomics and Applications (grant MG05-0401-2-0) from the Ministry of Science and Technology (MOST) of the Republic of Korea.

\section{References}

Bruns, A., Rohde, M. \& Berthe-Corti, L. (2001). Muricauda ruestringensis gen. nov., sp. nov., a facultatively anaerobic, appendaged bacterium from German North Sea intertidal sediment. Int J Syst Evol Microbiol 51, 1997-2006.

Cowan, S. T. \& Steel, K. J. (1965). Manual for the Identification of Medical Bacteria. London: Cambridge University Press.

Ezaki, T., Hashimoto, Y. \& Yabuuchi, E. (1989). Fluorometric deoxyribonucleic acid-deoxyribonucleic acid hybridization in microdilution wells as an alternative to membrane filter hybridization in which radioisotopes are used to determine genetic relatedness among bacterial strains. Int J Syst Bacteriol 39, 224-229.

Ivanova, E. P., Gorshkova, N. M., Sawabe, T., Zhukova, N. V., Hayashi, K., Kurilenko, V. V., Alexeeva, Y., Buljan, V., Nicolau, D. V. \& other authors (2004). Sulfitobacter delicatus sp. nov. and Sulfitobacter dubius sp. nov., respectively from a starfish (Stellaster equestris) and sea grass (Zostera marina). Int J Syst Evol Microbiol 54, $475-480$.

Komagata, K. \& Suzuki, K. (1987). Lipids and cell-wall analysis in bacterial systematics. Methods Microbiol 19, 161-203.

Labrenz, M., Tindall, B. J., Lawson, P. A., Collins, M. D., Schumann, P. \& Hirsch, P. (2000). Staleya guttiformis gen. nov., sp. nov. and Sulfitobacter brevis sp. nov., $\alpha$-3-Proteobacteria from hypersaline, heliothermal and meromictic antarctic Ekho Lake. Int J Syst Evol Microbiol 50, 303-313.
Lanyi, B. (1987). Classical and rapid identification methods for medically important bacteria. Methods Microbiol 19, 1-67.

Leifson, E. (1963). Determination of carbohydrate metabolism of marine bacteria. J Bacteriol 85, 1183-1184.

Pukall, R., Buntefuß, D., Frühling, A., Rohde, M., Kroppenstedt, R. M., Burghardt, J., Lebaron, P., Bernard, L. \& Stackebrandt, E. (1999). Sulfitobacter mediterraneus sp. nov., a new sulfite-oxidizing member of the $\alpha$-Proteobacteria. Int J Syst Bacteriol 49, 513-519.

Sasser, M. (1990). Identification of bacteria by gas chromatography of cellular fatty acids. Technical Note 101. Newark, DE: MIDI Inc.

Sorokin, D. Y. (1995). Sulfitobacter pontiacus gen. nov., sp. nov. - a new heterotrophic bacterium from the Black Sea, specialized on sulfite oxidation. Microbiology (English translation of Mikrobiologiia) 64, 354-365.

Stackebrandt, E. \& Goebel, B. M. (1994). Taxonomic note: a place for DNA-DNA reassociation and 16S rRNA sequence analysis in the present species definition in bacteriology. Int J Syst Bacteriol 44, 846-849.

Tamaoka, J. \& Komagata, K. (1984). Determination of DNA base composition by reverse-phase high-performance liquid chromatography. FEMS Microbiol Lett 25, 125-128.

Wagner-Döbler, I., Rheims, H., Felske, A., El-Ghezal, A., Flade-Schröder, D., Laatsch, H., Lang, S., Pukall, R. \& Tindall, B. J. (2004). Oceanibulbus indolifex gen. nov., sp. nov., a North Sea alphaproteobacterium that produces bioactive metabolites. Int J Syst Evol Microbiol 54, 1177-1184.

Wayne, L. G., Brenner, D. J., Colwell, R. R., Grimont, P. A. D., Kandler, O., Krichevsky, M. I., Moore, L. H., Moore, W. E. C., Murray, R. G. E. \& other authors (1987). International Committee on Systematic Bacteriology. Report of the ad hoc committee on reconciliation of approaches to bacterial systematics. Int $J$ Syst Bacteriol 37, 463-464.

Yoon, J.-H., Kim, H., Kim, S.-B., Kim, H.-J., Kim, W. Y., Lee, S. T., Goodfellow, M. \& Park, Y.-H. (1996). Identification of Saccharomonospora strains by the use of genomic DNA fragments and rRNA gene probes. Int J Syst Bacteriol 46, 502-505.

Yoon, J.-H., Lee, S. T. \& Park, Y.-H. (1998). Inter- and intraspecific phylogenetic analysis of the genus Nocardioides and related taxa based on 16S rRNA gene sequences. Int J Syst Bacteriol 48, 187-194.

Yoon, J.-H., Kang, K. H. \& Park, Y.-H. (2003). Psychrobacter jeotgali sp. nov., isolated from jeotgal, a traditional Korean fermented seafood. Int J Syst Evol Microbiol 53, 449-454. 